\title{
STRESS STRAIN ANALYSIS OF STANDARD AND HIGH STRENGTH CONCRETE
}

\author{
BITTLA SUDHEER $^{1} \&$ JAGDISH CHAND ${ }^{2}$ \\ ${ }^{I}$ Research Scholar, Masters in Structural Engineering, Chandigarh University (CU), Mohali, Punjab, India \\ ${ }^{2}$ Associate Professor, UIE-Civil Engineering, Chandigarh University, Mohali, Punjab, India
}

\begin{abstract}
This documentation presents the analysis of standard and high strength concrete with stress-strain relation. Many researchers have been performed on stress-strain analysis by using UTM machineries and other analytical works, but this paper includes usage of Compress meter for finding of stress-strain analysis. To know the perfect behaviour of any material we need to analyze ultimate strength, strain and its maximum elasticity, and the values obtained are clearly mentioned in the main content in form of tables and graphs. We all know that high strength concrete is the higher load resistance material obtained by reducing water-cement ratio and adding super plasticizers. This research work includes the different trial works to obtain high strength concrete and the maximum obtained strength is $77.1 \mathrm{~N} / \mathrm{mm} 2$ and other values are clearly mentioned in conclusion and graphs with different curing periods (i.e. 14, 28, 56, 90 days of curing).

KEYWORDS: Ultimate Strength, UTM Machines, Elasticity, Compress Meter
\end{abstract}

Received: Jun 10, 2020; Accepted: Jun 30, 2020; Published: Jul 21, 2020; Paper Id.: IJMPERDJUN2020407

\section{INTRODUCTION}

We all know that different types of researches are going on concrete from the past two decades, different types of materials and chemicals are developed to obtain the high strength concrete by replacing the cement and other materials of concrete. Here in this research work I have been replaced the cement with silica fume and reduced the water-cement ratio to 0.23 and added the Tamcem 60R superplasticizer.

High strength concrete is very much different from the standard concrete in form of strength, materials, mixing, etc. The main important features of high strength concrete are higher load resistance, against chemical attacks, durability, etc.

\section{MATERIALS AND TRIALS FOR HIGH STRENGTH CONCRETE}

There is no specific code for the high strength concrete mean like standard concrete, one has to perform different trial methods until they obtain the designed high strength concrete. Here I have mentioned the materials and the specific codes used.

Cement-OPC 43 grade and tests are performed according to IS-12269-1989.

Aggregates- Tests are performed according to IS: 2386 (part 1-8).

Water- bacterial free water and codes used are IS 3025-1964 and revised edition IS 456- 2009.

Silica fume- It is the material obtained from coal industry which is 100 times smaller than the cement.

Superplasticizer- Different superplasticizers are there in the market which is used to reduce water- cement 
ratio, one can use any Superplastizer available in the market with care full instructions and guidance of chaperons. I have been used Tamcem 60R Superplastizer, where it can be used at 1.5 to $2.0 \%$ weight of cement.

All the densities of different materials mentioned above are clearly given in the table number 1.

Table 1: Mix Proportions and Densities

\begin{tabular}{|l|c|c|c|c|}
\hline \multicolumn{1}{|c|}{ Mix No } & M1 & M2 & M3 & M4 \\
\hline Cement $(\mathrm{Kg} / \mathrm{m} 3)$ & 564.29 & 455.01 & 505.82 & 546.09 \\
\hline Fine aggregate $(\mathrm{Kg} / \mathrm{m} 3)$ & 689.23 & 727.82 & 698.02 & 689.23 \\
\hline Coarse aggregate $(\mathrm{Kg} / \mathrm{m} 3)$ & 1143.8 & 1207.83 & 1187.4 & 1143.8 \\
\hline Water(kg/m3) & 137.9 & 137.9 & 137.9 & 137.9 \\
\hline W/C ratio & 0.23 & 0.27 & 0.25 & 0.23 \\
\hline Slump & 75 & 80 & 80 & 80 \\
\hline Silica fume $(\mathrm{Kg} / \mathrm{m} 3)$ & 42.47 & 50.55 & 55.83 & 60.67 \\
\hline Superplasticizer & $1.5 \%$ of cement & $1.5 \%$ of cement & $1.7 \%$ of cement & $1.8 \%$ of cement \\
\hline
\end{tabular}

Four trials have been done, in which Mix 4 has obtained the high strength of $70.9 \mathrm{~N} / \mathrm{mm} 2$. For the comparison of high strength concrete, I have elected the normal grade concrete of M25 grade. The strengths of each cube are clearly mentioned in form of graphs for standard and high strength concrete.

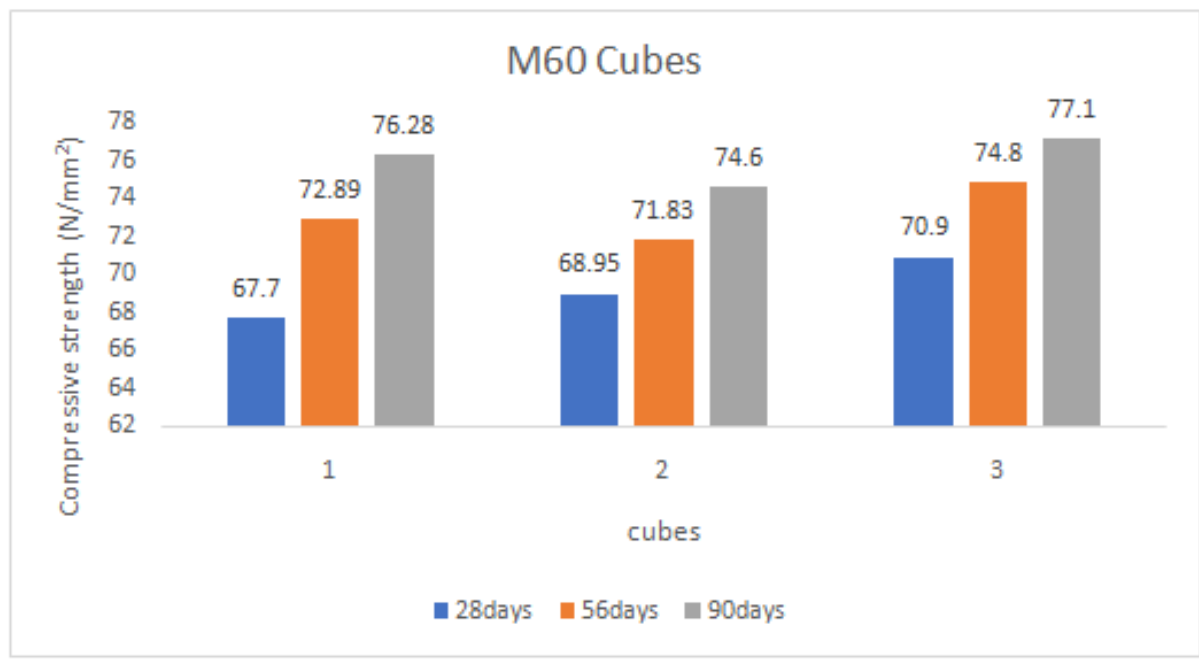

Figure 1: Compressive Strength of M60 Cubes.

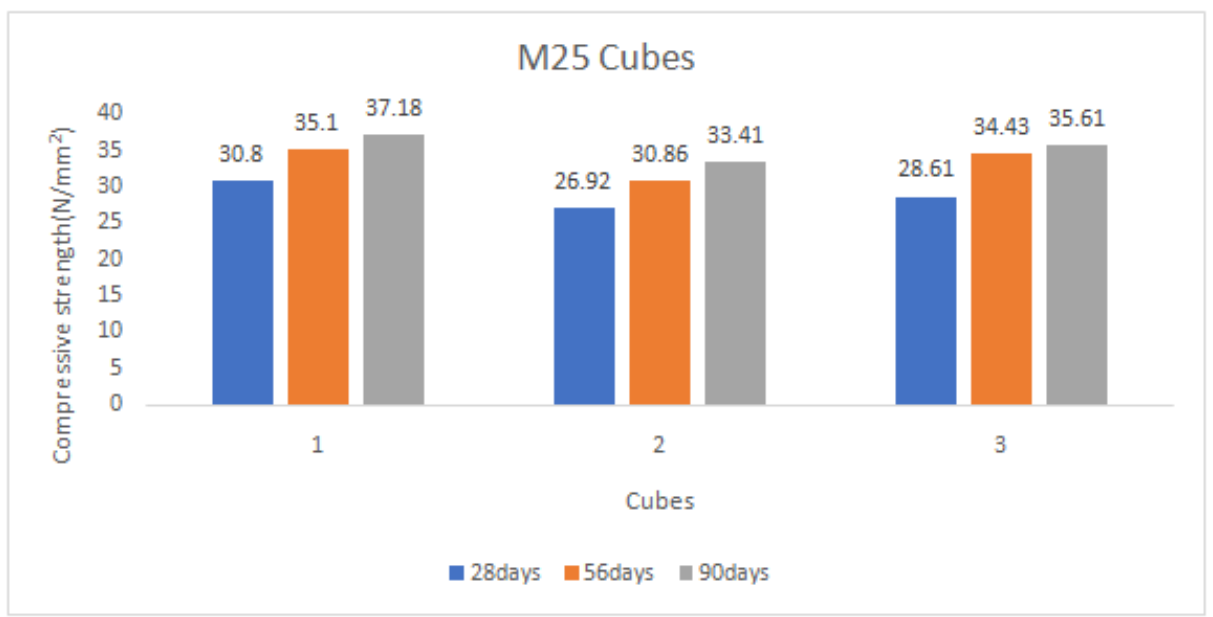

Figure 2: Compressive Strength of M25 Cubes. 


\section{METHODOLOGY FOR STRESS STRAIN ANALYSIS}

To find the stress and strain the gauge length of the Compress meter and area of cylinder is to calculated.

- The ratio of the gauge value to the gauge length is the strain in cylinder, were as gauge value is the dial reading of the Compressometer.

Strain $=$ Gauge value/Gauge length .

Gauge length is equal to $150 \mathrm{~mm}$ which is the diameter of the cylinder.

- $\quad$ Stress is calculated by the formula load to the area

Stress $=$ Load $/$ area

Area $=17662.5 \mathrm{~mm}^{2}$.

- $\quad$ Modulus of elasticity $=$ stress $/$ strain

Different graphs were plotted for stress strain behavior of each cylinder with various curing periods.

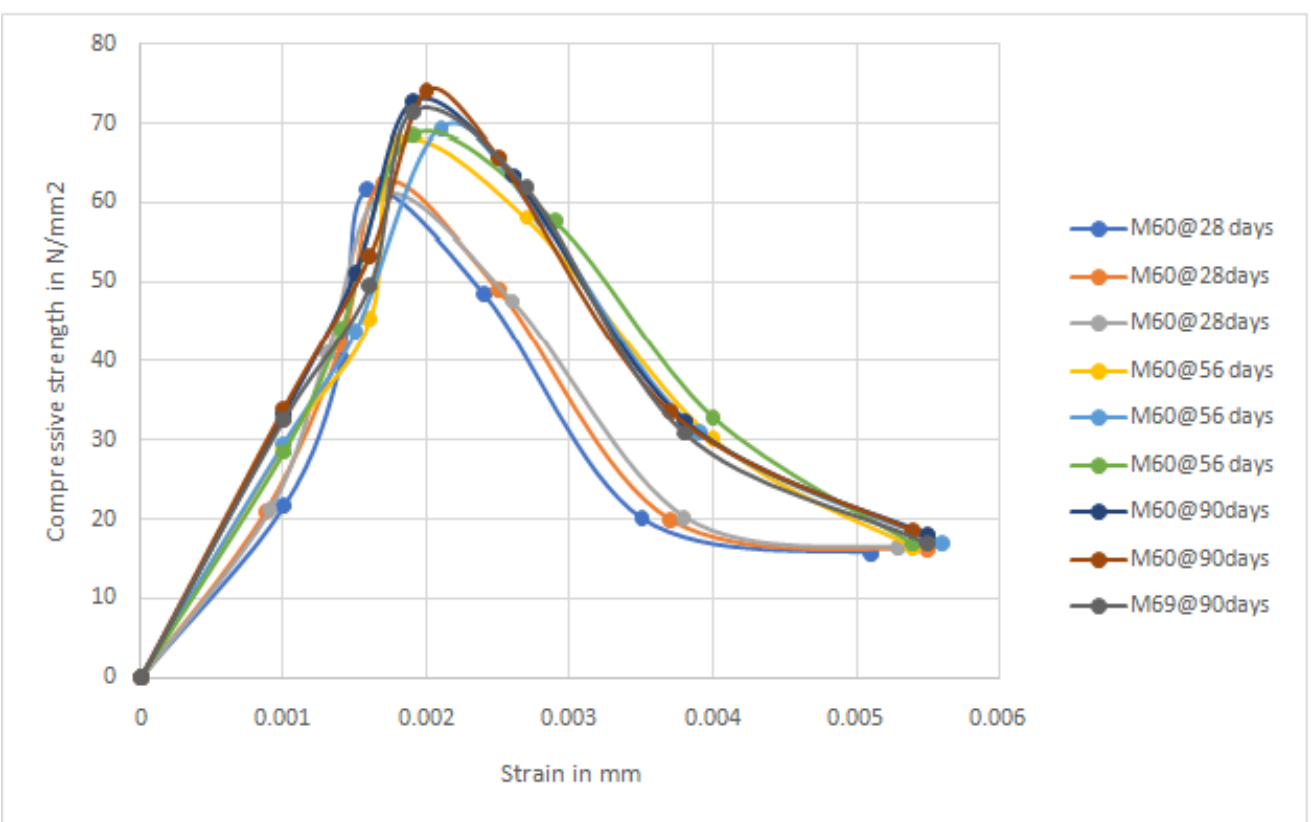

Figure 3: Stress-Strain Graph of M60 Grade Concrete. 


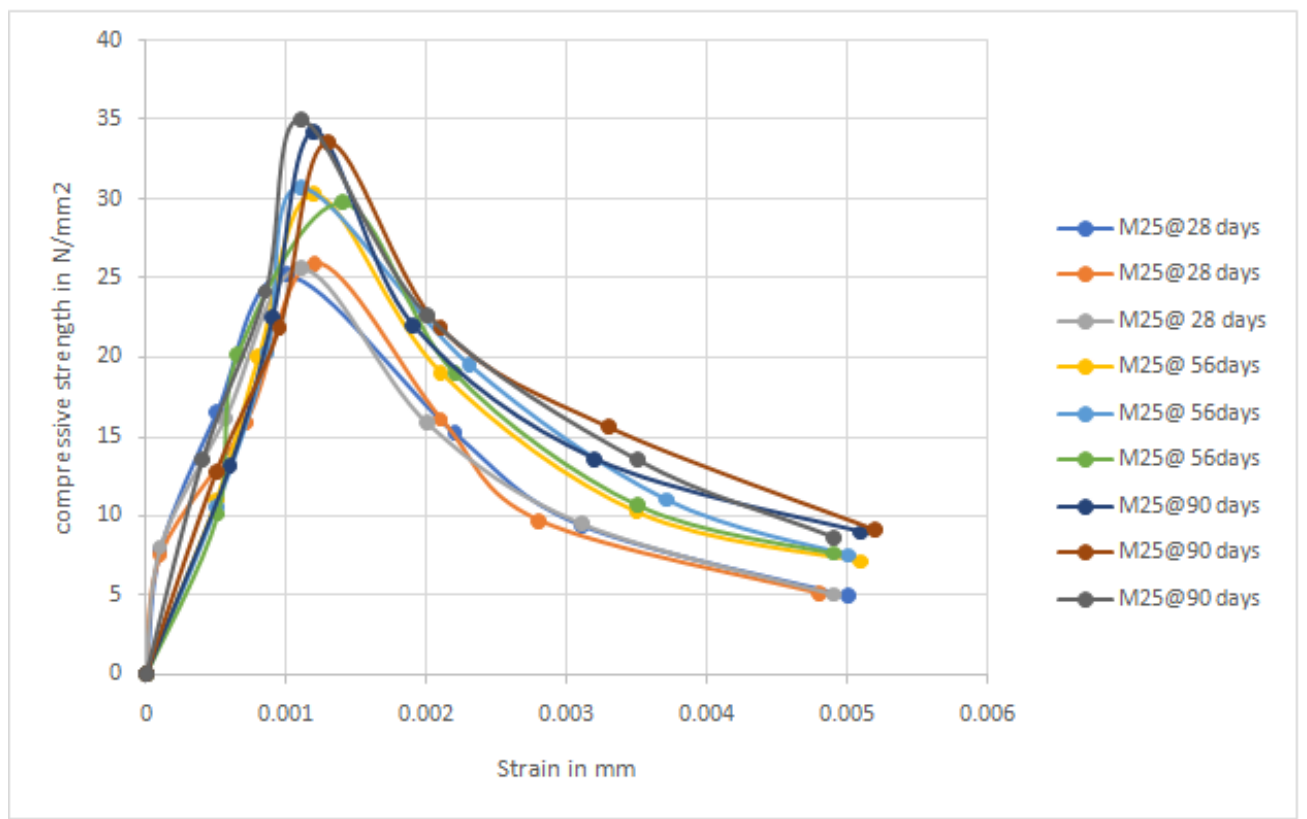

Figure 4: Stress-Strain Graph of M25 Grade Concrete.

The above graphs show the variation in stress-strain of M60 and M25 grade concrete for 28, 56, 90 days of curing.

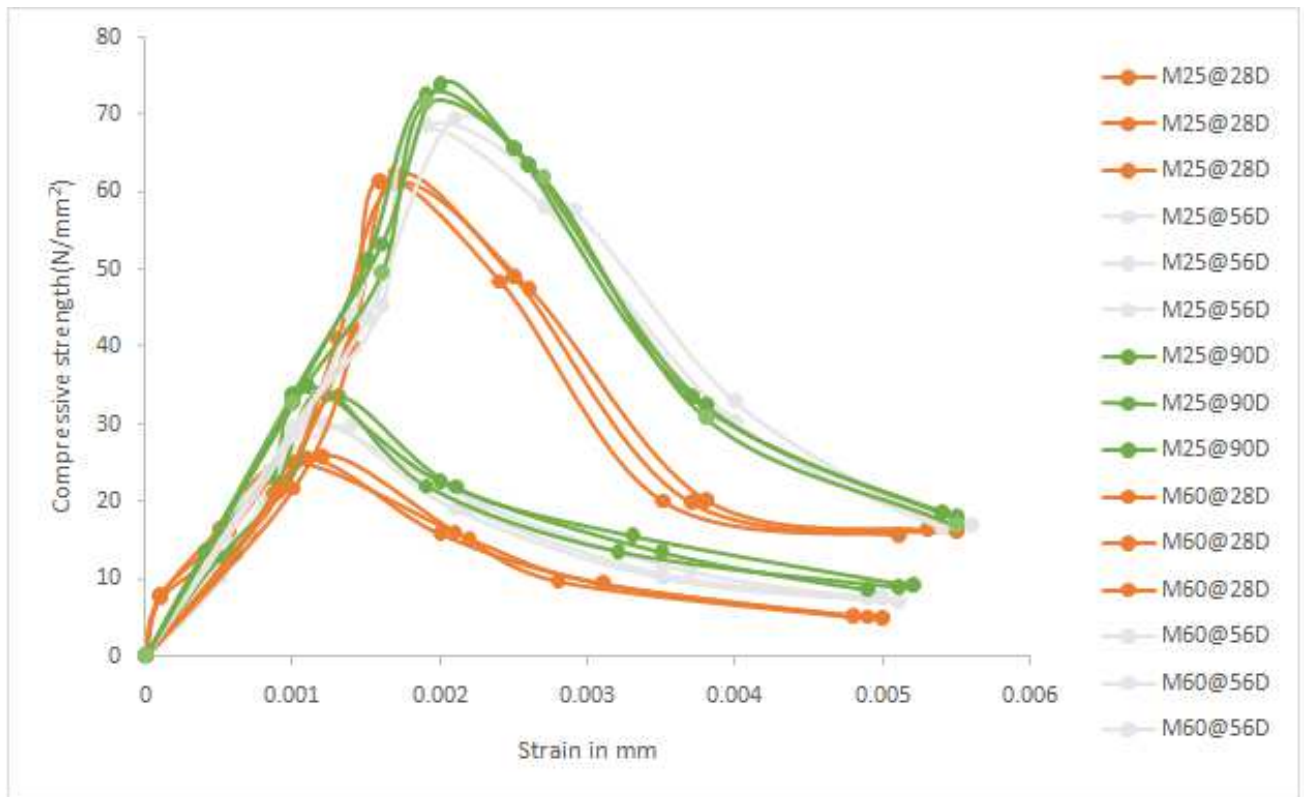

Figure 5: Comparison of Stress-Strain Graph for M60 Grade and M25 Grade.

\section{CONCLUSIONS}

- The trial mix number 4 of M60 grade with $10 \%$ replacement of silica fume and 0.23 water- cement ratios gave the satisfactory results with $70.9 \mathrm{~N} / \mathrm{mm} 2$ for 28 days, $72.89 \mathrm{~N} / \mathrm{mm} 2$ and $77.1 \mathrm{~N} / \mathrm{mm} 2$ for 90 days of curing.

- The elasticity and strain observed are clearly mentioned in the below given table. 
Table 2

\begin{tabular}{|c|c|c|c|c|c|c|c|c|c|}
\hline \multirow{2}{*}{ Age } & \multicolumn{3}{|c|}{ 28 days } & \multicolumn{3}{c|}{ 56days } & \multicolumn{3}{c|}{ 90 days } \\
\cline { 2 - 11 } & Max stress & Strain & $\mathbf{E}\left(\mathbf{N} / \mathbf{m m}^{2}\right)$ & Max stress & Strain & $\mathbf{E}\left(\mathbf{N} / \mathbf{m m}^{2}\right)$ & Max stress & Strain & $\mathbf{E}\left(\mathbf{N} / \mathbf{m m}^{2}\right)$ \\
\hline M25 & 25.60 & 0.0011 & 23387.22 & 30.26 & 0.00123 & 24808.86 & 34.29 & 0.0012 & 28740.83 \\
\hline M60 & 61.7 & 0.0016 & 35061.9 & 68.65 & 0.0019 & 35632.8 & 72.77 & 0.0020 & 37651.7 \\
\hline
\end{tabular}

\section{REFERENCES}

1. Tiefeng Chen, Xiaojian Gao And Miao Ren "Effects of Autoclave Curing and Fly Ash on Mechanical Properties of UltraHigh-Performance Concrete”, Journal of Construction and Building Materials, Vol. 158, pp.864-872, 2018.

2. Jonathan, Ahmed Ibrahim, Riyadh" Analytical compressive stress strain model for high strength concrete confined with srossspirals"Engineering structures, Vol-113, pp-362-370,2016.

3. Le'geron F, Paultre P” Uniaxial confinement model for normal- and high-strength concrete columns", ASCE Journal, Volume-129, No-2, pp 241-252, 2003.

4. Ibrahim A.E.M. Shehata,lidia, Tales $S$ "Stress strain curve for the design of high strength concrete elements" Materials and structures"Vol-33,pp 411-418,aug-sep 2000.

5. Daniel, Cusson, Patrick "Stress strain model for confined high strength concrete”, Journal of structural engineering, vol121,pp-468-477,1995.

6. Cusson D, Paultre P, " Stress-strain model for confined high-strength concrete”, ASCE Journal, Volume-121, No-3, pp 468477, 1995.

7. ACI Committee 211," Guide for selecting proportions for High strengths concrete with Portland cement and Fly ash" ACI Materials Journal, Volume 90, Number 3, pp 272-283,1993.

8. IS 456:2000," Indian standard, Plane and reinforced concrete”, Bureau of Indian Standards, New Delhi.

9. IS 10262-2009” IS Method of mix design “Bureau of Indian Standards, New Delhi, India.

10. Sargin M," Stress-strain relationship for concrete and the analysis of structural concrete section", Ph.D. thesis, University of Waterloo, Ontario, Canada, 1971.

11. Aziz, Omar Q., and Bahman O. Taha. "Mechanical properties of high strength concrete (HSC) with and without chopped carbon fiber (CCF)." International journal of civil engineering (IJCE), 2.1 (2013): 1-12.

12. Lee, D. J., et al. "Slender Concrete Wall Behavior Predicted by Finite Element Analysis." International Journal of Civil, Structural, Environmental and Infrastructure Engineering Research and Development (IJCSEIERD) 6.4 (2016):11-18.

13. Mohammed, Samir, Ata El-Kareim Shoeib, and Mostafa. Abd El-Megied. "Effect of Discrete Steel Fibers on the Behaviour of RC Beams Exposed to Fire." International Journal of Civil, Structural, Environmental \& Infrastructure (IJCSEIERD) 4.5 (2014):47-58.

14. Patel, H. S., and H. S. Patel. "Effect On Compressive And Flexural Strength Of High-Performance Concrete Incorporating Alccofine And Fly Ash." International Journal of Civil, Structural, Environmental and Infrastructure Engineering Research and Development (IJCSEIERD) 3.2 (2013): 109-114. 


\section{AUTHORS PROFILE}

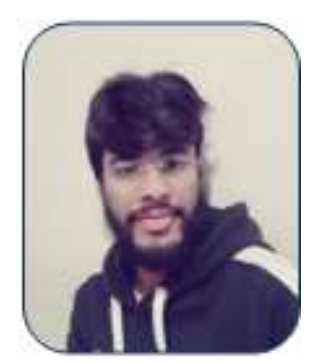

“Bittla Sudheer" currently pursuing Masters in structural engineering from Chandigarh University (CU), Mohali, Punjab, India. He received his bachelor's degree from Institute of aeronautical engineering college Affliated under Jawaharlal Nehru Technological University, Hyderabad, Telangana, his area of research is on standard concrete and high strength concrete.

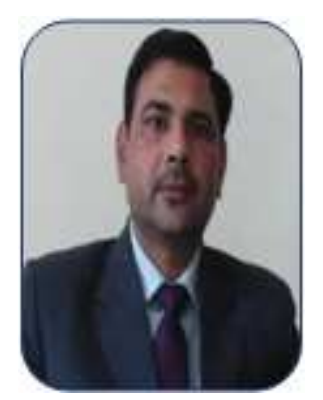

“Jagdish Chand” holds a bachelor's degree in Civil Engineering, master's degree in Structural Engineering and pursuing his Ph.D. degree from the National Institute of Technology, Kurukshetra. He is an Associate Professor in UIECivil Engineering at Chandigarh University, Mohali. He has over six years of industrial experience and more than twelve years of teaching experience. His area of interest includes cementitious materials, high strength concrete, steel-concrete composite structures. 